\title{
OXIDATION OF METHANE IN BIOTRICKLING FILTERS INOCULATED WITH METHANOTROPHIC BACTERIA
}

\author{
Manuel Cáceres* ${ }^{1}$, Antonio D. Dorado ${ }^{1,2}$, Juan C. Gentina ${ }^{1}$, Germán Aroca ${ }^{1}$ \\ ${ }^{1}$ School of Biochemical Engineering, Pontificia Universidad Católica de Valparaíso.Av. Brasil 2085, \\ Valparaíso, Chile. \\ ${ }^{2}$ Manresa School of Engineering, Universitat Politècnica de Catalunya, Av. Bases de Manresa 61-73, 08242 \\ Manresa, España
}

\begin{abstract}
The oxidation of methane $\left(\mathrm{CH}_{4}\right)$ using biofilters has been proposed as an alternative to mitigate anthropogenic greenhouse gas emissions with low concentration of $\mathrm{CH}_{4}$ that cannot be used as a source of energy. However conventional biofilters utilize organic packing materials that have a short lifetime, clogging problems and are commonly inoculated with non-specific microorganisms leading to unpredictable $\mathrm{CH}_{4}$ elimination capacities (EC) and removal efficiencies (RE). The main objective of this work was to characterize the oxidation of $\mathrm{CH}_{4}$ in two biotrickling filters (BTFs) packed with polyethylene rings and inoculated with two methanotrophic bacteria Methylomicrobium album and Methylocystis sp. in order to determine the $\mathrm{CH}_{4}$ elimination capacity (EC) and $\mathrm{CO}_{2}$ production $\left(\mathrm{pCO}_{2}\right)$ when using a specific inoculum. The repeatability of the results in both BTF was determined when operated at the same inlet load of $\mathrm{CH}_{4}$. A dynamic mathematical model that describes the $\mathrm{CH}_{4}$ abatement in the BTFs was developed and validated using mass transfer and kinetic parameters estimated independently. Results showed that EC and $\mathrm{pCO}_{2}$ of the BTFs are not identical but very similar at all the conditions tested. The use of specific inoculum has shown a faster start-up and higher EC per unit area $\left(0.019 \mathrm{~g}_{\mathrm{CH} 4} \cdot \mathrm{m}^{-2} \cdot \mathrm{h}^{-1}\right)$ in comparison to most of previous studies at the same $\mathrm{CH}_{4}$ load rate $\left(23.2 \mathrm{~g}_{\mathrm{CH} 4} \cdot \mathrm{m}^{-3} \cdot \mathrm{h}^{-1}\right)$. Global mass balance shown that the maximum reduction of $\mathrm{CO}_{2}$ equivalents was $98.5 \mathrm{~g}_{\mathrm{CO} 2 \mathrm{eq}} \cdot \mathrm{m}^{-3} \cdot \mathrm{h}^{-1}$. Model developed described satisfactorily $\mathrm{CH}_{4}$ abatement in BTFs in a wide range of conditions.
\end{abstract}

Key words: biofiltration, biotrickling filters, greenhouse gases, global warming, methane oxidation, methanotrophs.

*Corresponding Author: e-mail: manuel.caceres.s@mail.pucv.cl, tel.: 56-32-2273641, fax: 56-32-2273803. 


\section{INTRODUCTION}

Methane $\left(\mathrm{CH}_{4}\right)$ is considered the second largest contributor to the greenhouse effect with a global warming potential (GWP) of about 23 times greater than carbon dioxide $\left(\mathrm{CO}_{2}\right)$. For this reason there is a growing interest in reducing anthropogenic emissions of this gas when its use as source of energy is not feasible due to its low concentration. There are many anthropogenic sources of gaseous emissions with such characteristic that are emitted to the atmosphere, such as those emitted from abandoned landfills, livestock facilities, animal husbandry and some sections of wastewater treatment plants. In all these cases, the microbial oxidation of $\mathrm{CH}_{4}$ could be a low cost solution compared with physical/chemical technologies (Lopez et al. 2013). This biotechnology takes advantage of the ability of methane-oxidizing bacteria (MOB), also called methanotrophs, which utilize $\mathrm{CH}_{4}$ as a source of carbon and energy (Sohngen, 1906). In MOBs the incorporation of $\mathrm{CH}_{4}$ into the metabolism is mediated by the enzyme methane monooxygenase (MMO) that oxidase $\mathrm{CH}_{4}$ to methanol. In a second reaction, methanol is converted to formaldehyde by a methanol dehydrogenase. Then, the carbon from $\mathrm{CH}_{4}$ follows its catabolism by the RuMP or serine pathway depending on the type of microorganism, giving rise to the classification of methanotrophs type I and II respectively, being assimilated to biomass or released as carbon dioxide $\left(\mathrm{CO}_{2}\right)$ (Hanson and Hanson 1996).

The bio-oxidation of $\mathrm{CH}_{4}$ has been applied in landfills using covers of compost bio-augmented with MOBs, achieving good $\mathrm{CH}_{4}$ reductions but without control of the operational conditions (Scheutz et al. 2009; Sadasivam and Reddy 2014). Different configurations of closed bioreactors, like traditional biofilters and biotrickling filters (BTFs), have been tested looking for an improved configuration that allows a better control of the factors that determine the rate of $\mathrm{CH}_{4}$ bio-oxidation (Nikiema et al. 2009; Rocha-Ríos et al. 2009; Pfluger et al. 2011; Veillete et al. 2011). Traditional biofilters generally utilize organic materials, like soil or compost, as support of the microbial communities established in biofilms over the surfaces of the particles that at the same time can be source of nutrients for the microorganisms. In the bio-oxidation of $\mathrm{CH}_{4}$ these organic materials have shown to have a short lifetime $(<6$ months) and problems associated with channeling, clogging and pressure drop in long-term operations (Veillete et al. 2012). In BTFs a biofilm develops on an inorganic material and nutrients are provided by a recirculating solution. Inorganic packing materials have several advantages like good mechanical resistance, low-pressure drop and a more stable behavior in long-term operation. BTFs have been used to study the effect of nutrients concentrations, $\mathrm{pH}$ and 
temperature on the bio-oxidation of $\mathrm{CH}_{4}$ because it allows a better control of the operation conditions. Until now there have been reported the use of non-specific microbial communities like active sludge or natural inoculation for the bio-oxidation of $\mathrm{CH}_{4}$ in biofiltration systems. Table 1 shows a summary of the values reported by different authors using inorganic and organic materials as a support for non-specific microbial communities. There are no reports of bio-oxidation of $\mathrm{CH}_{4}$ using BTFs inoculated with pure cultures of methanotrophic bacteria.

Table 1 Bio-oxidation of $\mathrm{CH}_{4}$ in different reactors with different inoculum and packing materials

The use of non-specific microbial communities can lead to long startup periods and different communities can evolve obtaining different performances. Although biofiltration studies generally do not have duplicate systems to evaluate the repeatability in biofilters (Jimenez et al. 2016) the complexity of the mechanisms involved leads to accept that repeatability is not ensured. In this sense the use of specific methanotrophic bacteria as inoculum of a BTF can be an effective way to get more reproducible $\mathrm{CH}_{4}$ results that can be predicted through a dynamic model that considers the kinetic parameters of these microorganisms and mass transport processes of the system. There are few reports on the modeling and simulation of the biofiltration of $\mathrm{CH}_{4}$ probably due to the scarce experimental data to build and validate reliable models. Mrazovac et al. 2012 focused on the preliminary stage of the biological degradation of $\mathrm{CH}_{4}$; the diffusion of $\mathrm{CH}_{4}$ in water by irreversible absorption and desorption. Ordaz et al. (2014) characterized the impact of a non-aqueous phase on the kinetics of $\mathrm{CH}_{4}$ bio-oxidation using respirometry techniques. Only one empirical model has been reported and was developed for a compost-based biofilter (Plessis 2003). Nikiema et al. (2009b) proposed a model for the biofiltration of $\mathrm{CH}_{4}$ taking into account the variables concentration, velocity and temperature. This model simulates the biofiltration of $\mathrm{CH}_{4}$ at steady conditions in a range of concentrations between 1500 and $9500 \mathrm{ppm}$ and considering a constant biomass concentration. Other studies determining kinetic parameters of methanotrophs have set different kinetic parameters for different concentrations ranges (Delhoménie et al. 2008; Ménard et al. 2014; Rodrigues et al. 2009; Boiesen et al. 1993; Ordaz et al. 2014).

The main objective of this work was to characterize the oxidation of $\mathrm{CH}_{4}$ in biotrickling filters (BTFs) inoculated with Methylomicrobium album and Methylocystis sp., type I and type II methanotrophic bacteria respectively, assessing the $\mathrm{CH}_{4}$ bio-oxidation repeatability through a statistical comparison of two identical BTFs. A 
comprehensive dynamic model of the bio-oxidation of $\mathrm{CH}_{4}$ using BTFs was also developed and validated using the experimental set of data.

\section{MATERIALS AND METHODS}

\section{Biotrickling filters set up}

Two identical biotrickling filters (BTFs) were set up using transparent tubes of polyvinyl chloride (PVC) of $0.153 \mathrm{~m}$ internal diameter (ID) and $1.20 \mathrm{~m}$ of height with gas sampling ports located every $30 \mathrm{~cm}$ from inlet to outlet. Polyethylene rings $\left(\mathrm{OD}=15 \mathrm{~mm}\right.$, ID $=13 \mathrm{~mm}, \mathrm{H}=10 \mathrm{~mm}$, density $1.02 \mathrm{~kg} \cdot \mathrm{L}^{-1}$, external specific area $316 \mathrm{~m}^{-1}$ and $77 \%$ void fraction) were used as a support for the biofilm. The total packing volume (V) was 20 L. Both BTFs were inoculated with active cultures of methanotrophic bacteria type I and II, Methylomicrobium album (ATCC 33003) and Methylocystis sp. (ATCC 49242), grown using $\mathrm{CH}_{4}$ as sole carbon and energy source in a nitrate mineral salts liquid medium (NMS, ATCC 1306). The composition of NMS medium was: $1.0 \mathrm{~g} \cdot \mathrm{L}^{-1} \mathrm{MgSO}_{4} \mathrm{x} 7 \mathrm{H}_{2} \mathrm{O}, 0.2 \mathrm{~g} \cdot \mathrm{L}^{-1}$ $\mathrm{CaCl}_{2} \mathrm{x} 6 \mathrm{H}_{2} \mathrm{O}, 1.0 \mathrm{~g} \cdot \mathrm{L}^{-1} \mathrm{KNO}_{3}, 0.272 \mathrm{~g} \cdot \mathrm{L}^{-1} \mathrm{KH}_{2} \mathrm{PO}_{4}, 0.717 \mathrm{~g} \cdot \mathrm{L}^{-1} \mathrm{Na}_{2} \mathrm{HPO}_{4} \mathrm{x} 12 \mathrm{H}_{2} \mathrm{O} .2 .0 \mathrm{ml}$ of a chelated iron solution and $0.5 \mathrm{ml}$ of a trace elements solution was also added to $1 \mathrm{~L}$ of the NMS solution. Chelated Iron Solution: Ferric (III): $1.0 \mathrm{~g} \cdot \mathrm{L}^{-1}$ ammonium citrate, $2.0 \mathrm{~g} \cdot \mathrm{L}^{-1}$ EDTA sodium salt, $0.3 \mathrm{ml}$ of HCl (concentrated), $100 \mathrm{ml}$ of distilled deionized water. Trace Element Solution: $0.5 \mathrm{~g} \cdot \mathrm{L}^{-1}$ EDTA, $0.2 \mathrm{~g} \cdot \mathrm{L}^{-1} \mathrm{FeSO}_{4} \mathrm{x} 7 \mathrm{H}_{2} \mathrm{O}, 0.01 \mathrm{~g} \cdot \mathrm{L}^{-1} \mathrm{ZnSO}_{4} \mathrm{x} 7 \mathrm{H}_{2} \mathrm{O}, 0.003$ $\mathrm{g} \cdot \mathrm{L}^{-1} \mathrm{MnCl}_{2} \mathrm{x} 4 \mathrm{H}_{2} \mathrm{O}, 0.03 \mathrm{~g} \cdot \mathrm{L}^{-1} \mathrm{H}_{3} \mathrm{BO}_{3}, 0.02 \mathrm{~g} \cdot \mathrm{L}^{-1} \mathrm{CoCl}_{2} \mathrm{x} 6 \mathrm{H}_{2} \mathrm{O}, 0.001 \mathrm{~g} \cdot \mathrm{L}^{-1} \mathrm{CaCl}_{2} \mathrm{x} 2 \mathrm{H}_{2} \mathrm{O}, 0.002 \mathrm{~g} \cdot \mathrm{L}^{-1} \mathrm{NiClx} 6 \mathrm{H}_{2} \mathrm{O}$, $0.003 \mathrm{~g} \cdot \mathrm{L}^{-1} \mathrm{Na}_{2} \mathrm{MoO}_{4} \mathrm{x} 2 \mathrm{H}_{2} \mathrm{O}$.

The BTFs were continuously fed with a mixture of pre-humidified air and pure $\mathrm{CH}_{4}(99.8 \% \mathrm{v} / \mathrm{v})$. Different $\mathrm{CH}_{4}$ concentrations were obtained by mixing air and $\mathrm{CH}_{4}$ using two mass flow controllers (AFC-37, Aalborg, USA). Inlet concentrations $\left(\left[\mathrm{CH}_{4}\right]_{\text {in }}\right)$ between $0.5 \%-3.9 \%(\mathrm{v} / \mathrm{v})$ of $\mathrm{CH}_{4}$ were fed initially at different gas flow rates to determine the best condition for kinetic tests. The gas flow rate $(F)$ used were between $0.2-1.0 \mathrm{~L} \cdot \mathrm{min}^{-1}$. $\mathrm{CH}_{4}$ and $\mathrm{CO}_{2}$ were measured on line using an IR detector and $\mathrm{O}_{2}$ using an electrochemical sensor with a multigas analyzer (Xam 5600, Dräger, Germany). Fresh NMS medium (0.5 L) was supplied every day by spraying it to the top of the columns at rate of $0.5 \mathrm{~L} \cdot \mathrm{min}^{-1}$. Figure 1 shows a diagram of the experimental setup used for the oxidation of $\mathrm{CH}_{4}$ in $\mathrm{BTFs}_{\text {. }}$ 
Fig. 1 Diagram of the experimental system for the oxidation of $\mathrm{CH}_{4}$ in biotrickling filters.

The BTFs operation was characterized by measuring the $\mathrm{CH}_{4}$ removal efficiency $(R E)$ in \%, and the $\mathrm{CH}_{4}$ elimination capacity $(E C)$ in $\mathrm{gCH}_{4} \cdot \mathrm{m}^{-3} \cdot \mathrm{h}^{-1}$ at different $\mathrm{CH}_{4}$ loads $(L)$ in $\mathrm{gCH}_{4} \cdot \mathrm{m}^{-3} \cdot \mathrm{h}^{-1}$ after reaching steady state. Production of $\mathrm{CO}_{2}\left(p C \mathrm{O}_{2}\right)$ in $\mathrm{gCO}_{2} \cdot \mathrm{m}^{-3} \cdot \mathrm{h}^{-1}$ and consumption of $\mathrm{O}_{2}\left(\mathrm{cO}_{2}\right)$ in $\mathrm{gO}_{2} \cdot \mathrm{m}^{-3} \cdot \mathrm{h}^{-1}$ were also measured. A steady state was considered to be reached when $R E$ have a variation less than $5 \%$ in consecutive days. These parameters were determined according to the following equations:

$$
\begin{aligned}
& R E=\frac{\left[\mathrm{CH}_{4}\right]_{\text {in }}-\left[\mathrm{CH}_{4}\right]_{\text {out }}}{\left[\mathrm{CH}_{4}\right]_{\text {in }}} \cdot 100 \\
& E C=\left(\left[\mathrm{CH}_{4}\right]_{\text {in }}-\left[\mathrm{CH}_{4}\right]_{\text {out }}\right) \cdot \frac{F}{V} \\
& L=\left[\mathrm{CH}_{4}\right]_{\text {in }} \cdot \frac{F}{V} \\
& p C \mathrm{O}_{2}=\left(\left[\mathrm{CO}_{2}\right]_{\text {out }}-\left[\mathrm{CO}_{2}\right]_{\text {in }}\right) \cdot \frac{F}{V} \\
& c \mathrm{O}_{2}=\left(\left[\mathrm{O}_{2}\right]_{\text {out }}-\left[\mathrm{O}_{2}\right]_{\text {in }}\right) \cdot \frac{F}{V}
\end{aligned}
$$

Repeatability assessment

The repeatability of $\mathrm{CH}_{4}$ bio-oxidation in the BTFs was evaluated with two indicators: EC and $\mathrm{pCO}_{2}$; using the paired samples Student's t-test according to the methodology proposed by Jimenez et al. (2016). A two-tailed hypothesis testing was used considering that the mean of the differences is equal to zero, i.e. no significant differences exist between BTFs, at a 95\% confidence level. Repeatability between BTFs is established qualitatively when the calculated $t$ value is under a specific tabulated $T_{\text {critical }}$ value, based on the degrees of freedom of the data set $(\mathrm{n}-1)$. Similarly, no significant difference exists between biofilters for a $\mathrm{p}$-value $>0.05$. 
Model of the bio-oxidation of $\mathrm{CH}_{4}$ in a biotrickling filter

The model developed here considers the most relevant phenomena occurring during the biofiltration process for the bio-oxidation of $\mathrm{CH}_{4}$ in a biotrickling filter like advection, absorption and diffusion. The assumptions underlying this model are based on a consolidated model reported previously ( Dorado et al. 2012):

(1) Gas phase circulation regime is modelled as plug flow pattern. Thus, axial dispersion is not considered.

(2) Gas-biofilm interface equilibrium is described by Henry's law.

(3) Planar geometry and perpendicular diffusion in biofilm are used to derive model equations considering that the solid support size is significantly higher than the biofilm thickness. Diffusion in the biofilm is described by Fick's law.

(4) Biofilm is formed on the external surface of the packing material. Thus, biomass does not grow in the pores of the packing material and reactions only take place in the biofilm phase.

(5) Physical properties of the species in the biofilm are assumed to be the same as in water since this is the main component.

(6) There is no accumulation of biomass in the filter bed in each period and biomass properties (thickness, specific surface area and kinetic coefficients) are uniform along the bed.

(7) Adsorption of pollutant onto the support is neglected due to the low pollutant concentration and the low adsorption capacity of the packing material. Moreover, under steady-state conditions, the adsorption process is in equilibrium.

Dynamic mass balances in the gas phase and within the biofilm serve to describe changes in the biodegradation capacity of the biofilter during operation, overcoming the limitations of previous biofiltration models. The resulting equations are summarized as following:

$$
\frac{\partial\left[\mathrm{CH}_{4}\right]}{\partial t}=-v_{z} \cdot \frac{\partial\left[\mathrm{CH}_{4}\right]}{\partial z}-\frac{a}{\varepsilon} k_{g}\left(\left[\mathrm{CH}_{4}\right]-\frac{\left[C \mathrm{CH}_{4}\right]}{H}\right)
$$




$$
\frac{\partial\left[\mathrm{CH}_{4}\right]_{b}}{\partial t}=D_{B} \cdot \frac{\partial^{2}\left[\mathrm{CH}_{4}\right]_{b}}{\partial x^{2}}-\frac{1}{Y_{X / S}} \cdot \mu_{\max } \cdot \frac{\left[\mathrm{CH}_{4}\right]}{K_{S}+\frac{\left[C \mathrm{CH}_{4}\right]}{H}} \cdot X
$$

Where $\boldsymbol{v}_{\boldsymbol{z}}$ is the gas velocity in $\mathrm{m} \cdot \mathrm{h}^{-1} ; \mathbf{z}$ is the height position from the inlet in $\mathrm{m} ; \boldsymbol{a}$ is the specific surface area in $\mathrm{m}^{-1}$; $\varepsilon$ is the porosity; $\boldsymbol{k}_{\boldsymbol{g}}$ is the mass transfer coefficient in $\mathrm{m} \mathrm{h}^{-1} ; \boldsymbol{H}$ is the adimensional partition coefficient; $\left[\boldsymbol{C H}_{4}\right]_{\boldsymbol{b}}$ is the concentration in the biofilm in $\mathrm{g} \cdot \mathrm{m}^{-3} ; \boldsymbol{D}_{\boldsymbol{B}}$ is the diffusion coefficient for $\mathrm{CH}_{4}$ in the biofilm in $\mathrm{m} \cdot \mathrm{h}^{-1} ; \boldsymbol{Y}_{\boldsymbol{X} / \mathrm{s}}$ is the yield coefficient biomass/methane; $\boldsymbol{\mu}_{\max }$ is the maximum specific growth rate in $\mathrm{h}^{-1} ; \boldsymbol{K}_{\boldsymbol{S}}$ is the half saturation constant in $\mathrm{g} \cdot \mathrm{m}^{-3}$; and $\boldsymbol{X}$ is the biomass concentration in $\mathrm{g} \cdot \mathrm{m}^{-3}$.

With the following initial and boundary conditions:

$$
\begin{array}{ll}
\text { At } \mathrm{t}=0 & {\left[\mathrm{CH}_{4}\right]=0 \text { and }\left[\mathrm{CH}_{4}\right]_{b}=0 ;} \\
\mathrm{z}=0 & {\left[\mathrm{CH}_{4}\right]=\left[\mathrm{CH}_{4}\right]_{\text {in }}} \\
\mathrm{x}=0 & {\left[\mathrm{CH}_{4}\right]_{b}=\frac{\left[\mathrm{CH}_{4}\right]}{H}} \\
\mathrm{x}=\delta & \frac{\partial\left[\mathrm{CH}_{4}\right]_{b}}{\partial x}=0
\end{array}
$$

The resulting set of ordinary differential equations was solved using MATLAB. A variable order method was used for solving stiff differential equations based on the numerical differentiation formulas (NDFs). The parameter estimation was performed using a MATLAB algorithm based on a multidimensional unconstrained nonlinear minimization (Nelder-Mead) algorithm.

\section{Biofilter model parameters estimation}

The measuring of $\mathrm{CH}_{4}$ concentration in the gaseous phase of flasks containing an active culture of methanotrophs were used to characterize separately the kinetic of $\mathrm{CH}_{4}$ bio-oxidation by methanotrophs type I and II for initial concentrations between 1.0 and $6.8 \mathrm{~g} \mathrm{~m}^{-3}$ of $\mathrm{CH}_{4}$. Maximum specific growth rate $\left(\mu_{\max }\right)$ and half saturation constant $\left(\mathrm{K}_{\mathrm{S}}\right)$ were determined by using a dynamic model of the batch culture of the microorganisms using methane as a sole source of carbon and energy. In this model the specific growth rate $(\mu)$ is replaced by Monod expression (equations 8 
and 9). A non-linearization process minimizing the norm of the differences between experimental $\mathrm{CH}_{4} \mathrm{Concentration}$ and the model predictions was used for determining the parameters.

$$
\begin{aligned}
\frac{d\left[\mathrm{CH}_{4}\right]}{d t} & =-\frac{1}{Y_{X / S}} \cdot \mu_{\max } \cdot \frac{\left[\mathrm{CH}_{4}\right]}{K_{S}+\frac{\left[\mathrm{CH}_{4}\right]}{H}} \cdot X \\
\frac{d X}{d t} & =\frac{\mu_{\max }}{H} \cdot \frac{\left[\mathrm{CH}_{4}\right]}{K_{S}+\frac{\left[\mathrm{CH}_{4}\right]}{H}} \cdot X
\end{aligned}
$$

\section{RESULTS AND DISCUSSION}

\section{Elimination capacity}

Figure 2 shows the $\mathrm{CH}_{4}$ elimination capacity (EC) of the BTFs operated both in parallel at the same $\mathrm{CH}_{4}$ inlet load. The maximum $\mathrm{CH}_{4}$ elimination capacity $\left(\mathrm{EC}_{\max }\right.$ ) reached was in average $6.2 \mathrm{gCH}_{4} \cdot \mathrm{m}^{-3} \cdot \mathrm{h}^{-1}$ at an inlet load of 23.2 $\mathrm{g}_{\mathrm{CH} 4} \cdot \mathrm{m}^{-3} \cdot \mathrm{h}^{-1}$ given by an inlet $\mathrm{CH}_{4}$ concentration of $3.9 \%(\mathrm{v} / \mathrm{v})$. Compared with other studies using similar reactor volumes (Table 1) the $\mathrm{EC}_{\max }$ was low, probably due to the low specific area of the polyethylene rings used as packing material for biofilm formation in the BTFs. However, the maximum specific elimination capacity $\left(\mathrm{EC}_{\mathrm{sp}}\right)$ was $0.019 \mathrm{~g}_{\mathrm{CH} 4} \cdot \mathrm{m}^{-2} \cdot \mathrm{h}^{-1}$ being greater than the values reported by Nikiema et al. (2009a) at the same inlet load of $\mathrm{CH}_{4}$ using packing materials with similar and higher specific area, indicating that the high biological $\mathrm{CH}_{4}$ oxidation activity observed in this work could be related to the use of massive specific methanotrophic inoculum. Likewise, Rocha-Ríos et al. (2009) reported a $\mathrm{EC}_{\mathrm{sp}}$ of $0.037 \mathrm{~g}_{\mathrm{CH} 4} \cdot \mathrm{m}^{-2} \cdot \mathrm{h}^{-1}$ in a BTF using polyurethane foam as support with specific area of $600 \mathrm{~m}^{-1}$ and inoculated with a methanotrophic consortium. Figure 3 shows photographs taken with scanning electron microscopy (SEM, Jeol/Jem 1200 EX II, camera Gatan ES500W Model 782, USA) of the biofilm formed on the surface of the rings used as support in the lower section of the BTFs. It is possible to observe that the methanotrophic bacteria were properly immobilized on packing material forming a robust biofilm with a similar degree of colonization in both BTFs.

Fig. 2 Elimination capacity (EC) of $\mathrm{CH}_{4}$ in BTF1 (०) and BTF2 (•) as function of the inlet load of $\mathrm{CH}_{4}(\mathrm{~L})$. 
Fig. 3 SEM pictures (5000x) of the biofilm formed in the external side of rings extracted from the lower section of BTF1 (a) and BTF2 (b).

Figure 4 shows that the average production of $\mathrm{CO}_{2}$ and the consumption of $\mathrm{O}_{2}$ in $\mathrm{BTFs}$ were almost equivalent to the stoichiometric amount of $\mathrm{CH}_{4}$ oxidized. The proposed stoichiometry for the complete oxidation of $\mathrm{CH}_{4}$ indicates that $1 \mathrm{~mol}$ of $\mathrm{CH}_{4}$ requires $2 \mathrm{~mol}$ of oxygen $\left(\mathrm{O}_{2}\right)$ to generate $1 \mathrm{~mol}$ of $\mathrm{CO}_{2}$ (Havran et al. 2011). The difference between the production of $\mathrm{CO}_{2}$ in the BTFs and the theoretical value obtained for the complete oxidation of $\mathrm{CH}_{4}$ can be explained by its use as carbon source for microbial growth. The low difference indicates that a high degree of mineralization was achieved in BTFs at inlet loads of $\mathrm{CH}_{4}$ lower than $10 \mathrm{~g}_{\mathrm{CH} 4} \cdot \mathrm{m}^{-3} \cdot \mathrm{h}^{-1}$.

Fig. $4 \mathrm{O}_{2}$ consumed $(\bullet)$ and $\mathrm{CO}_{2}$ produced $(\boldsymbol{\Lambda})$ as a function of $\mathrm{CH}_{4}$ elimination capacity.

A carbon mass balance was made considering the carbon from $\mathrm{CH}_{4}\left(C_{\mathrm{CH} 4}\right)$ and $\mathrm{CO}_{2}\left(C_{\mathrm{CO} 2}\right)$ in $\mathrm{gC} \cdot \mathrm{m}^{-3} \cdot \mathrm{h}^{-1}$ at the inlet and the outlet of the BTFs to estimate the amount of carbon accumulated $\left(\mathrm{C}_{\mathrm{ac}}\right)$ as biomass into the BTFs, Equations 8, 9 and 10. Figure 5 shows the $\mathrm{C}_{\mathrm{ac}}$ (in $\mathrm{gC} \cdot \mathrm{m}^{-3} \cdot \mathrm{h}^{-1}$ ) as function of the $\mathrm{CH}_{4}$ load. An estimation of the reduction of the global warming potential (GWP) in the gaseous stream was made considering that the GWP of $\mathrm{CH}_{4}$ is 23 related to the $\mathrm{CO}_{2}$ (Equation 11).

$C_{\text {in }}=\left(C_{\mathrm{CH} 4}\right)_{\text {in }}+\left(C_{\mathrm{CO} 2}\right)_{\text {in }}$

$C_{\text {out }}=\left(C_{\mathrm{CH} 4}\right)_{\text {out }}+\left(C_{\mathrm{CO} 2}\right)_{\text {out }}$

$C_{a c}=\left(C_{i n}-C_{o u t}\right)$

Red $G W P=\left(G W P_{\mathrm{CH} 4}\right) \cdot E C_{\mathrm{CH} 4}-p \mathrm{CO}_{2}$

For inlet loads of $\mathrm{CH}_{4}$ below $10 \mathrm{gCH}_{4} \mathrm{~m}^{-3} \mathrm{~h}^{-1}$ the amount of accumulated carbon in the BTFs $\left(C_{a c}\right)$ was around $0.1 \mathrm{gCm}^{-3} \mathrm{~h}^{-1}$ but when the load of $\mathrm{CH}_{4}$ was increased over $10 \mathrm{gCH}_{4} \mathrm{~m}^{-3} \mathrm{~h}^{-1}$ it was observed a proportional increase of accumulated carbon in the BTFs. This could be due to the higher availability of $\mathrm{CH}_{4}$ stimulate the growth of 
biomass. In addition methanotrophic bacteria are known for their ability to produce exopolysaccharides (EPS) at high methane flux rates (Huq et al. 1978). According to Equation 11 the maximum reduction of $\mathrm{CO}_{2}$ equivalents (Red GWP) was $98.5 \mathrm{gCO}_{2} \mathrm{~m}^{-3} \mathrm{~h}^{-1}$ at load of $23.2 \mathrm{gCH}_{4} \cdot \mathrm{m}^{-3} \cdot \mathrm{h}^{-1}$.

Fig. 5 Accumulated carbon $\left(\mathrm{C}_{\mathrm{ac}}\right)$ in the BTF1 ( $\left.\square\right)$ and BTF2 ( $\left.\mathbf{}\right)$

Figure 6 shows the concentrations of $\mathrm{CH}_{4}$ along the BTF1 at different empty bed residence times (EBRT), and the effect of different inlet concentration of $\mathrm{CH}_{4}$. The higher variation in the $\mathrm{CH}_{4}$ concentration along the column was observed in the first section of the BTF1. This effect was accentuated at inlet $\mathrm{CH}_{4}$ concentrations over $1.0 \% \mathrm{v} / \mathrm{v}$. The higher variation on $\mathrm{CH}_{4}$ concentration along the BTF1 was observed at the lower gas velocity tested (1.1 h of EBRT). A similar behavior was observed in the BTF2. This behavior is consistent with the decrease of $\mathrm{CH}_{4}$ and $\mathrm{O}_{2}$ concentration from the gas phase to the biofilm as the gas moves through the column of the BTFs and $\mathrm{CH}_{4}$ is oxidized, decreasing $\mathrm{CH}_{4}$ and $\mathrm{O}_{2}$ concentration. Due the high free volume given by polyethylene rings, clogging episodes or even increases of pressure drop after one year of continuous operation were not detected.

Fig. 6 Profiles of $\mathrm{CH}_{4}$ concentration along the height $(\mathrm{H})$ of the BTF1 at different inlet $\mathrm{CH}_{4}$ concentration and different empty bed residence time: $\bullet 67, \boldsymbol{\Delta} 50, \boldsymbol{\square} 40$, x 30 minutes.

\section{Operation repeatability}

Statistical analysis (Student's t test) of the data considering as hypothesis that the BTFs have identical EC and $\mathrm{pCO}_{2}$ (difference between the means is equal to zero) and 80 degrees of freedom indicated that significant differences between the BTFs were established since the calculated $t$ value was higher than the specific tabulated $T_{\text {critical }}$ value for both indicators. However, if is used a more flexible comparison criteria (like a reasonable difference between the means), the values measured for $\mathrm{EC}$ and $\mathrm{pCO}_{2}$ are quite similar between the BTFs to consider that the two systems of bio-oxidation of $\mathrm{CH}_{4}$ have similar behavior. Moreover when the statistical analysis was made by periods of operation, the results indicated an identical behavior $\left(t<T_{\text {critical }}\right)$ to the first 45 days of operation, after which their performance began to distancing probably due to the sum of small differences in the operation like channeling of the gas flow, temperature or $\mathrm{pH}$. In Table 2 are summarized the results for statistical analyses. 
Table 2 Results for statistical analyses for BTFs

Estimation of the kinetic parameters of the model

Figures 7 show the experimental data and the model simulation for the bio-oxidation of $\mathrm{CH}_{4}$ by Methylomicrobium album and Methylocystis sp. respectively, at different initial concentration of $\mathrm{CH}_{4}$.

Fig. 7 Experimental data (dots) and model estimation (lines) for the bio-oxidation of $\mathrm{CH}_{4}$ by (a) Methylomicrobium album and (b) Methylocystis sp. at different initial concentration of $\mathrm{CH}_{4}$.

The estimated kinetic parameters are presented in Table 3 for Methylomicrobium album and Methylocystis sp., respectively.

Table 3 Kinetics parameters for Methylomicrobium album and Methylocystis sp.

\section{Simulation of the bio-oxidation of $\mathrm{CH}_{4}$ in BTFs}

Figure 8 shows the effect of flow rate (i.e. contact time) on the RE measured experimentally and predicted for the model developed. In this figure the RE is normalized with respect to RE achieved at the most favorable condition of contact time (100 min) to evaluate the influence of the flow rate on the loss of efficiency at 3 different concentrations (0.5, 1 and $2 \%$ of $\left.\mathrm{CH}_{4}\right)$. RE at contact times of 100 min were respectively 28, 39 and $70 \%$ in ascending order of concentration in the case of BTF1 and 31, 40 and 78\% in the case of BTF2. Data analysis shows that, independently of methane inlet concentration, the effect of contact time is equivalent in both BTFs: from 0.2 to $0.61 \mathrm{~min}^{-1}$ the loss of efficiency is maximum (50\%), considerably inferior (25\%) between 0.6 and $1.0 \mathrm{l} \mathrm{min}^{-1}$, and being practically constant from then on (5\%). Thus, the critical effect of mass limitation due the low solubility of $\mathrm{CH}_{4}$ is highly sensitive between 30 and 100 min.

The degree of agreement between experimental RE and model predictions is significantly high according to Figure 8, demonstrating that the model proposed based on mass balances, transport phenomena and biological characterization 
can predict the observed behavior by means of a low set of parameters (Table 4). Mainly, it is noteworthy that the model proposed is able to describe satisfactorily 36 different situations were flow rate (from 0.2 to $2.0 \mathrm{l} \mathrm{min}^{-1}$ ); inlet concentration (0.5, 1.0 and 2.0\%) and bio-system (BTF1 and BTF2) were varied in each case. In this table is also possible to compare the parameters values with previous works reported in the field of methane biodegradation. Although in the present work the range of concentrations is wider than those previously studied, a unique set of parameters was able to describe all scenarios monitored, not differing significantly than those reported for other studies.

Table 4 Physical and kinetics parameters values for the bio-oxidation of $\mathrm{CH}_{4}$.

Fig. 8 Removal efficiency (RE) of $\mathrm{CH}_{4}$ in the BTFs as function of the gas flow rate at inlet $\mathrm{CH}_{4}$ concentrations of $0.5 \% \mathrm{v} / \mathrm{v}(\mathrm{x}), 1.0 \% \mathrm{v} / \mathrm{v}(\mathrm{\circ})$ and $2.0 \% \mathrm{v} / \mathrm{v}\left(^{*}\right)$ for model predictions (continuous lines) and experimental monitoring (discontinuous signs) in the case of BTF1 (a) and BTF2 (b).

\section{CONCLUSIONS}

The high degree of feasibility and reproducibility of $\mathrm{CH}_{4}$ bio-oxidation has been demonstrated in a long-term operation of 1 year for two identical biotrickling filters inoculated with methanotrophic bacteria type I and II, Methylomicrobium album and Methylocystis sp. The maximum $\mathrm{CH}_{4}$ elimination capacity reached was in average 6.2 $\mathrm{gCH}_{4} \cdot \mathrm{m}^{-3} \cdot \mathrm{h}^{-1}$. The use of specific inoculum has shown a faster start-up and higher EC per unit area $\left(0.019 \mathrm{~g}_{\mathrm{CH} 4} \cdot \mathrm{m}^{-}\right.$

${ }^{2} \cdot \mathrm{h}^{-1}$ ) in comparison to most of previous studies. Plant monitoring let to develop a more comprehensive mathematical model to describe $\mathrm{CH}_{4}$ biofiltration by means of kinetic and mass transport characterization that predicts the wide range of conditions tested with high agreement with the experimental observations.

\section{ACKNOWLEDGEMENTS}

This research was financed by the National Fund for Science and Technology (FONDECYT), Project 1110919, and the Pontificia Universidad Católica de Valparaíso. We thank Biofilm and Environmental Microbiology Laboratory of the Universidad de Concepción who helped us to get SEM pictures. 


\section{REFERENCES}

Avalos Ramírez A, García Aguilar B, Jones P, Heitz M (2012) Improvement of methane biofiltration by the addition of non-ionic surfactants to biofilters packed with inert materials. Process Biochemistry 47: 76-82

Boiesen A, Arvin E, Broholm K (1993) Effect of mineral nutrients on the kinetics of methane utilization by methanotrophs. Biodegradation 4(3): 163-170

Delhoménie MC, Nikiema J, Bibeau L, Heitz M (2008) A new method to determine the microbial kinetic parameters in biological air filters. Chemical Engineering Science 63(16): 4126-4134

Dorado AD, Baeza JA, Lafuente J, Gabriel D, Gamisans X (2012) Biomass accumulation in a biofilter treating toluene at high loads - Part 2: Model development, calibration and validation. Chemical Engineering Journal 209: 670-676

Estrada JM, Lebrero R, Quijano G, Pérez R, Figueroa-González I, García-Encina PA, Muñoz R (2014) Methane abatement in a gas-recycling biotrickling filter: Evaluating innovative operational strategies to overcome mass transfer limitations. Chemical Engineering Journal 253: 385-393

Girard M, Avalos Ramirez A, Buelna G, Heitz M (2011) Biofiltration of methane at low concentrations representative of the piggery industry-influence of the methane and nitrogen concentrations. Chem Eng $\mathrm{J}$ 168:151-158

Hanson R, Hanson T (1996) Methanotrophic Bacteria. Microbiological Reviews 60 (2): 439-471.

Havran V, Dudukovic M, Lo C (2011) Conversion of Methane and Carbon Dioxide to Higher Value Products. Ind. Eng. Chem. Res. 50:7089-7100

Huq MN, Ralph BJ, Rickard PAD (1978) The extracellular polysaccharide of a methylotrophic culture. Australian Journal of Biological Science 31: 311-316

Jimenez L, Arrieaga S, Aizpuru A (2016) Assessing biofiltration repeatability: statistical comparison of two identical toluene removal systems. Environmental Technology 37(6). doi: 10.1080/09593330.2015.1077894

López JC, Quijano G, Souza TS, Estrada JM, Lebrero R, Muñoz R (2013) Biotechnologies for greenhouse gases $\left(\mathrm{CH}_{4}, \mathrm{~N}_{2} \mathrm{O}\right.$ and $\left.\mathrm{CO}_{2}\right)$ abatement: state of the art and challenges. Appl Microbiol Biotechnol 97: 2277-2303

Ménard C, Ramirez AA Heitz M (2014) Kinetics of simultaneous methane and toluene biofiltration in an inert packed bed. Journal of Chemical Technology \& Biotechnology 89(4): 597-602

Mrazovac SM, Milan PR, Vojinovic-Miloradov MB, Tosic BS (2012) Dynamic model of methane-water diffusion. Applied Mathematical Modelling 36(9): 3985-3991

Nikiema J, Girard M, Brzezinski R, Heitz M (2009a) Biofiltration of methane using an inorganic filter bed: Influence of inlet load and nitrogen concentration. Canadian Journal of Civil Engineering 36(12): 1903-1910

Nikiema J, Payre G, Heitz M (2009b). A mathematical steady state model for methane bioelimination in a closed biofilter. Chemical Engineering Journal 150(2-3):418-425

Nikiema J, Heitz M (2010) The use of inorganic packing materials during methane biofiltration. International Journal of Chemical Enggineering, Volume 2010. Article ID 573149, 8 pages.

Ordaz A, López JC, Figueroa-González I, Muñoz R, Quijano G (2014) Assessment of methane biodegradation kinetics in two-phase partitioning bioreactors by pulse respirometry. Water Research 67: 46-54 
Perdikea K, Mehrotra AK, Hettiaratchi JP (2008) Study of thin biocovers (TBC) for oxidizing uncaptured methane emissions in biorreactor landfills. Waste Manag 28:1364-1274

Pfluger A, Wu WM, Pieja AJ, Wan J, Rostkowski K, Criddle C (2011) Selection of Type I and Type II methanotrophic proteobacteria in a fluidized bed reactor under non-sterile conditions. Bioresource Technology 102: 9919-9926

Plessis C (2003) Empirical model for methane oxidation using a composted pine bark biofilter. Fuel 82(11): 13591365

Rocha Ríos J, Bordel S, Hernández S, Revah S (2009) Methane degradation in two-phase partition bioreactors. Chemical Engineering Journal 152: 289-292

Rodrigues A, Valdman B, Salgado AM (2009) Analysis of methane biodegradation by Methylosinus trichosporium OB3b. Brazilian Journal of Microbiology 40(2): 301-307

Sadasivam BY, Reddy KR (2014) Landfill methane oxidation in soil and bio-based cover systems: a review. Rev Environ Sci Biotechnol 13:79-107

Scheutz C, Bogner J, De Visscher A, Gebert J, Hilger H, Huber-Humer M, Kjeldsen P, Spokas K (2009) Microbial methane oxidation processes and technologies for mitigation of landfill gas emissions. Waste Manag Res 27: 409455. doi: 10.1177/0734242X09339325

Sohngen NL (1906) Uber bakterien welche methan ab kohlenstoffnahrung und energiequelle gerbrauchen (On bacteria which use methane as a carbon and energy source). Z. Bakteriol. Parazitenk. (Infektionster) 15: 513-517

Veillete M, Viens P, Avalos Ramirez A, Brzezinski R, Heitz M (2011) Effect of ammonium concentration on microbial population and performance of a biofilter treating air polluted with methane. Chemical Engineering Journal 171:1114-1123

Veillete M, Girard M, Viens P, Brzezinski R, Heitz M (2012) Function and limits of biofilters for the removal of methane in exhaust gases from the pig industry. Appl Microbiol Biotechnol. 94 (3): 601-6011

\section{Table captions}

Table 1 Bio-oxidation of $\mathrm{CH}_{4}$ in different reactors with different inoculum and packing materials

Table 2 Statistical analysis of experimental results in Biotrickling filters

Table 3 Kinetics parameters for the bio-oxidation of $\mathrm{CH}_{4}$ by Methylomicrobium album and Methylocystis sp.

Table 4 Physical and kinetics parameters values for the bio-oxidation of $\mathrm{CH}_{4}$.

\section{Figures captions}

Fig. 1 Diagram of experimental system for the oxidation of $\mathrm{CH}_{4}$ in biotrickling filters.

Fig. 2 Elimination capacity (EC) of $\mathrm{CH}_{4}$ in BTF1 (०) and BTF2 (•) as function of the inlet load of $\mathrm{CH}_{4}(\mathrm{~L})$. 
Fig. 3 SEM pictures (5000x) of the biofilm formed in the external side of rings extracted from the lower section of BTF1 (a) and BTF2 (b).

Fig. 4 Moles of $\mathrm{O}_{2}$ consumed ( $\square$ ) and $\mathrm{CO}_{2}$ produced ( $\left.\mathbf{\Lambda}\right)$ as function of $\mathrm{CH}_{4}$ elimination capacity.

Fig. 5 Accumulated carbon $\left(\mathrm{C}_{\mathrm{ac}}\right)$ in the BTF1 ( $\left.\square\right)$ and BTF2 (- $)$

Fig. 6 Profiles of $\mathrm{CH}_{4}$ concentration along the height $(\mathrm{H})$ of the BTF1 at different inlet $\mathrm{CH}_{4}$ concentration and different empty bed residence time: $\bullet 7, \boldsymbol{\wedge} 50, \mathbf{4} 40$, x 30 minutes.

Fig. 7 Experimental data (dots) and model estimation (lines) for the bio-oxidation of $\mathrm{CH}_{4}$ by (a) Methylomicrobium album and (b) Methylocystis sp. at different initial concentration of $\mathrm{CH}_{4}$.

Fig. 8 Removal efficiency (RE) of $\mathrm{CH}_{4}$ in the BTFs as function of the gas flow rate at inlet $\mathrm{CH}_{4}$ concentrations of $0.5 \% \mathrm{v} / \mathrm{v}(\mathrm{x}), 1.0 \% \mathrm{v} / \mathrm{v}(\mathrm{\circ})$ and $2.0 \% \mathrm{v} / \mathrm{v}\left({ }^{*}\right)$ for model predictions (continuous lines) and experimental monitoring (discontinuous signs) in the case of BTF1 (a) and BTF2 (b). 
Figure 1 was created using Microsoft Office.

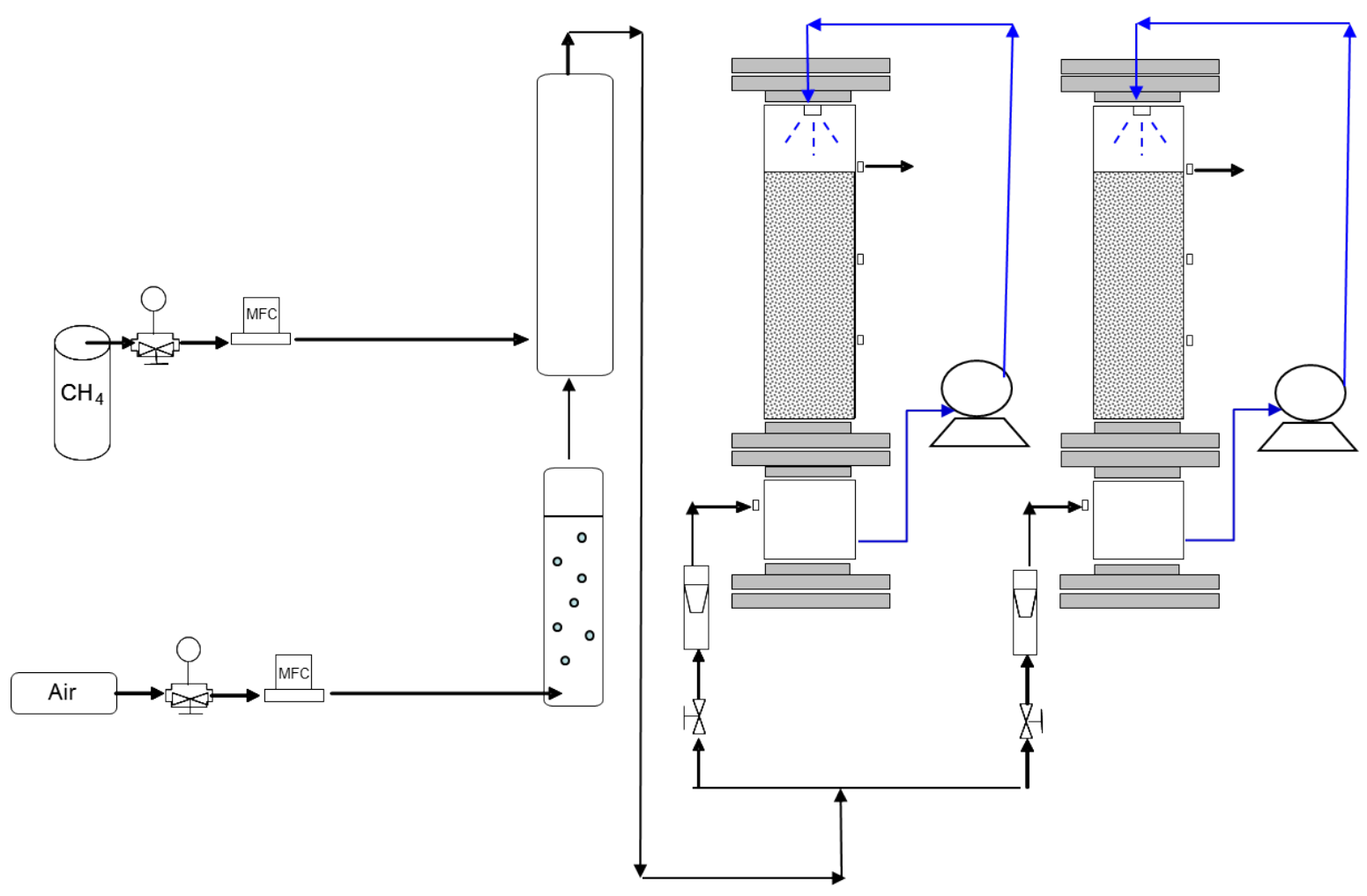


Figure 2 was created using Microsoft Office.

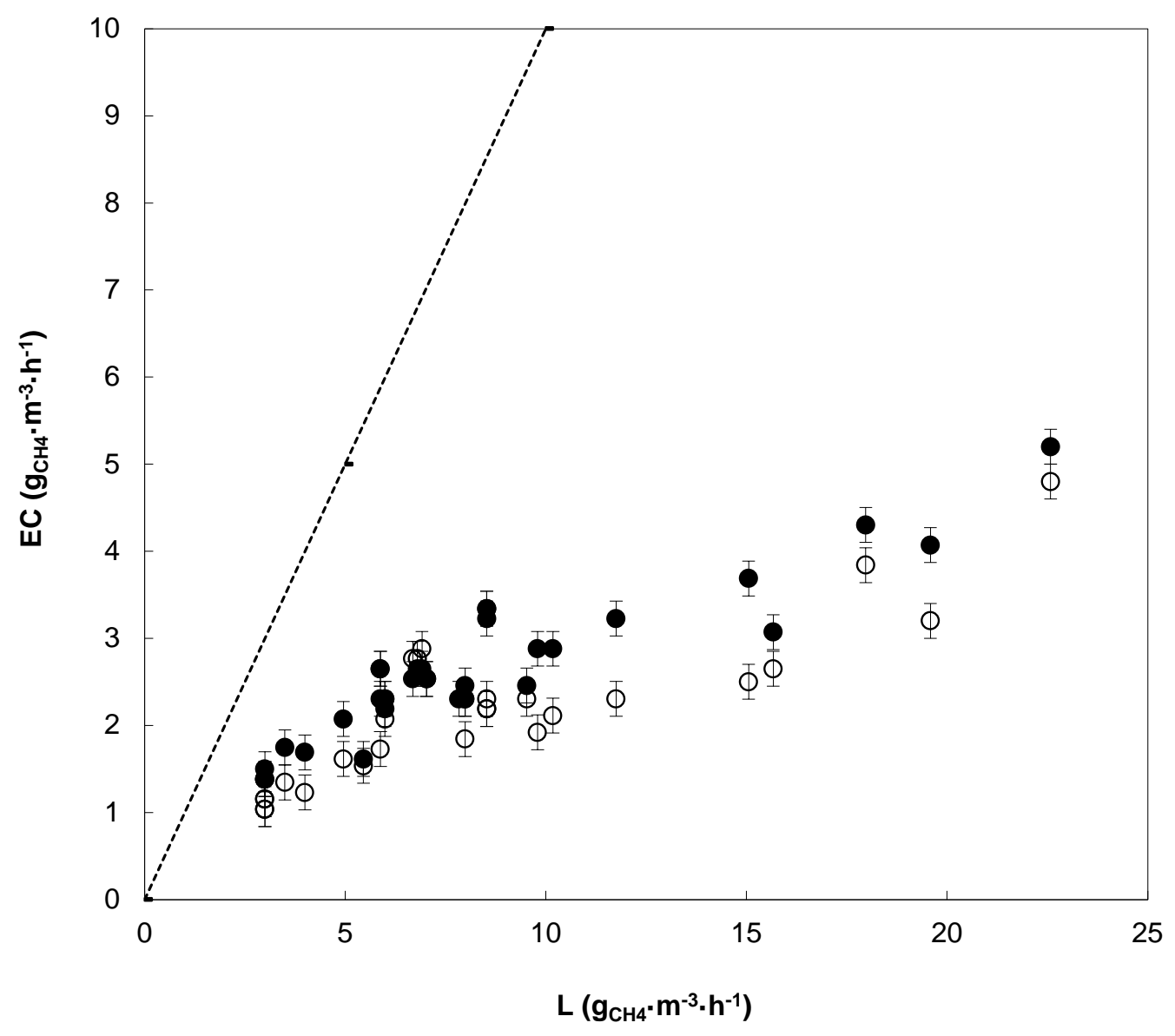


Figure 3. SEM pictures were taken using DigitalMicrograph (DM).
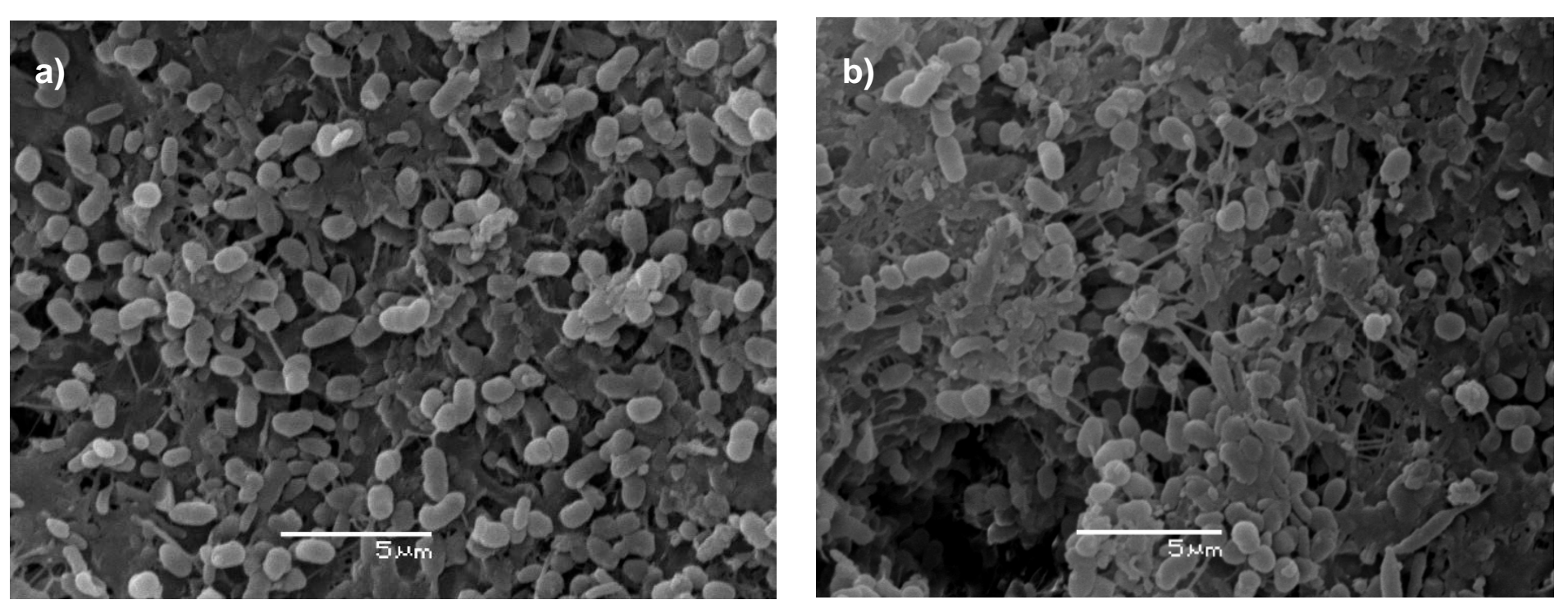
Figure 4 was created using Microsoft Office.

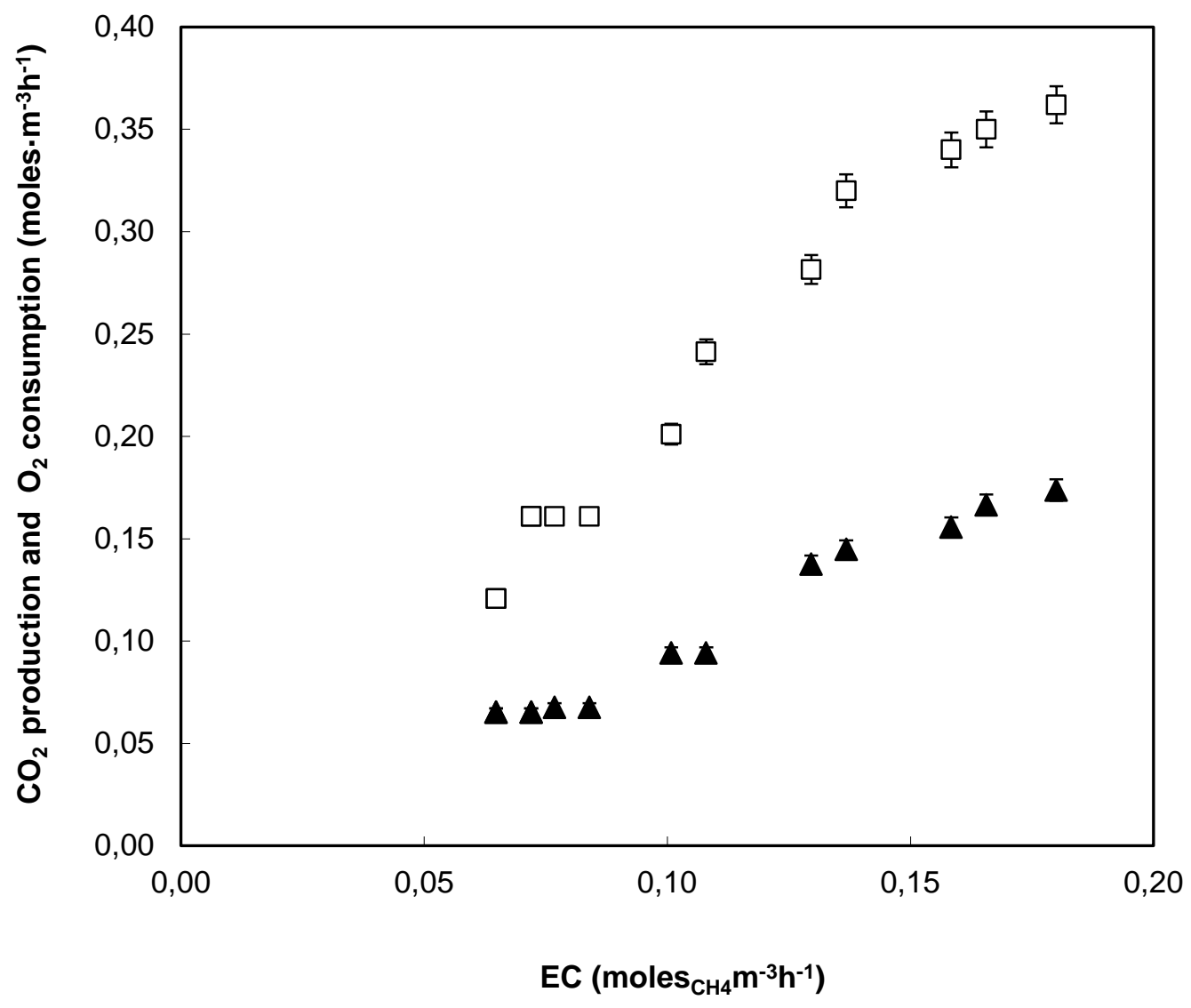


Figure 5 was created using Microsoft Office.

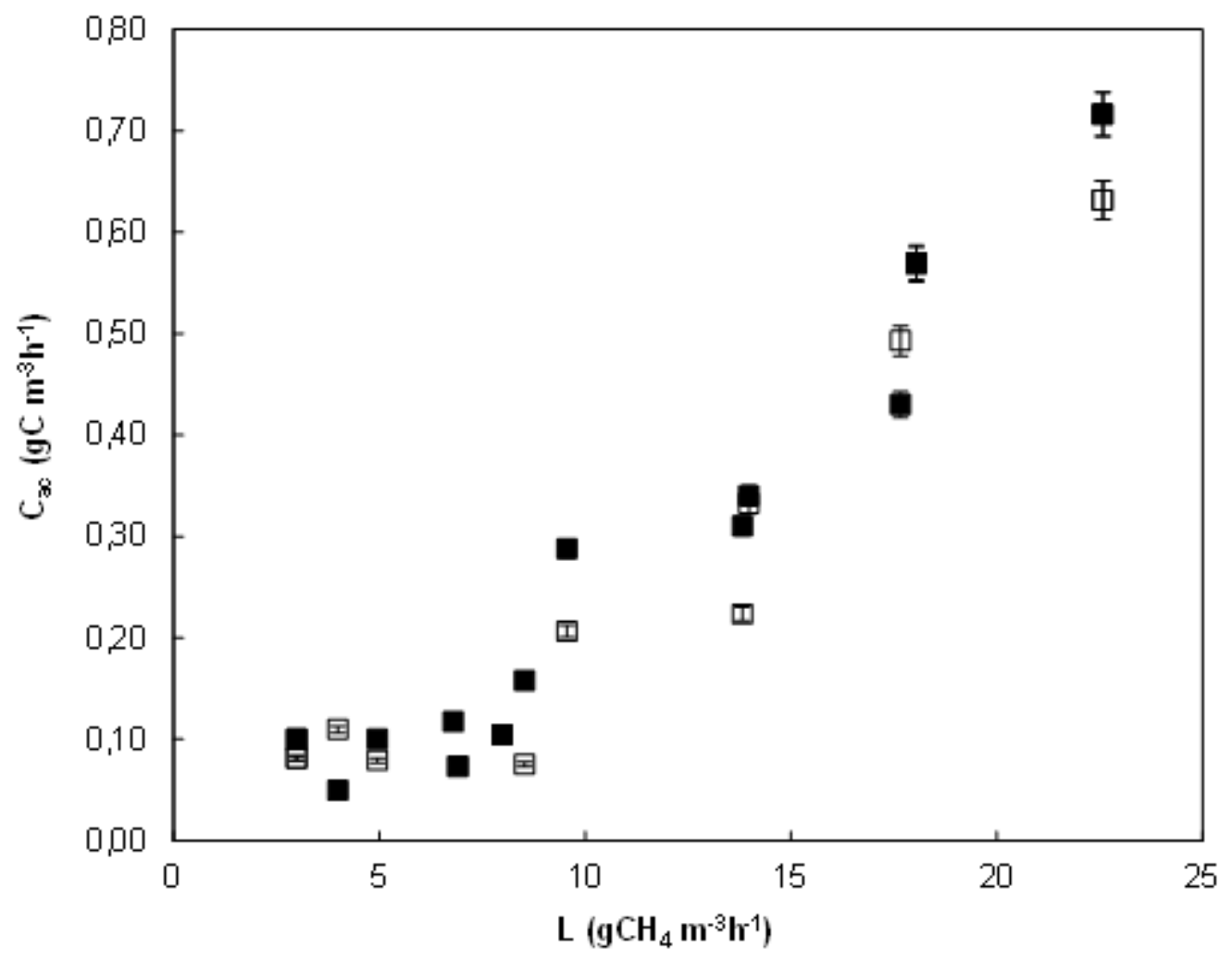


Figure 6 was created with Microsoft Office.

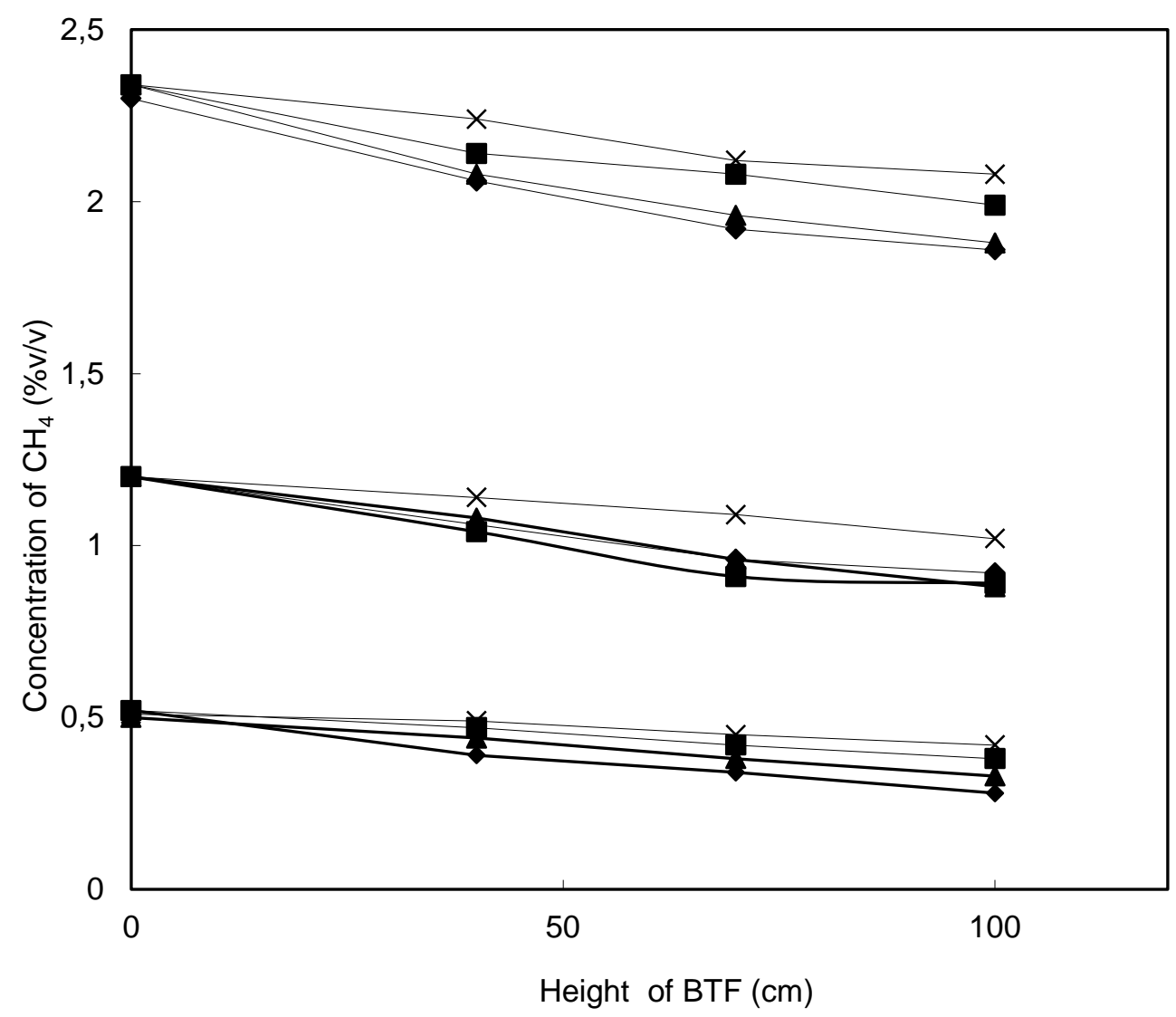


Figure 7 was created with MatLab.

a)

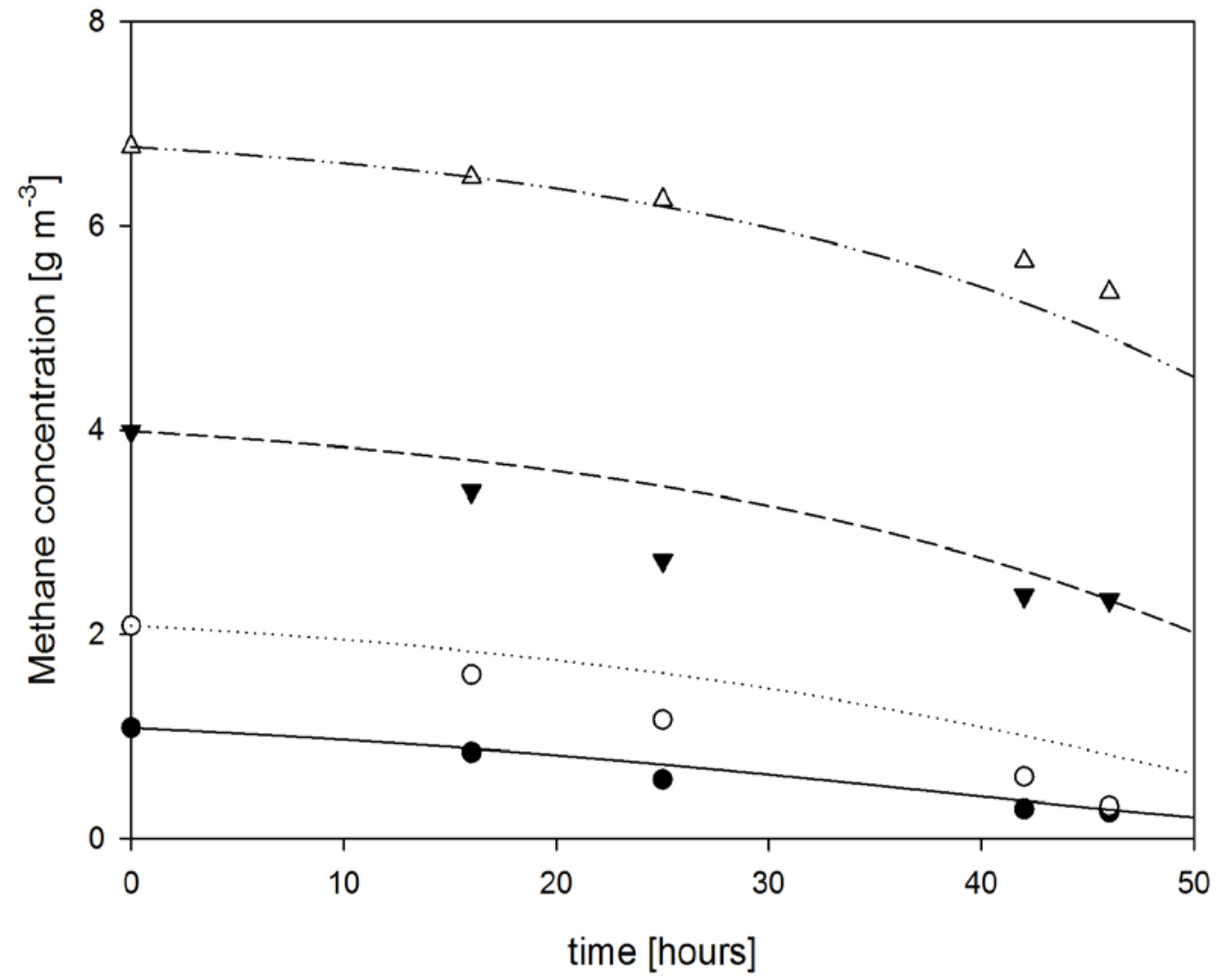


b)

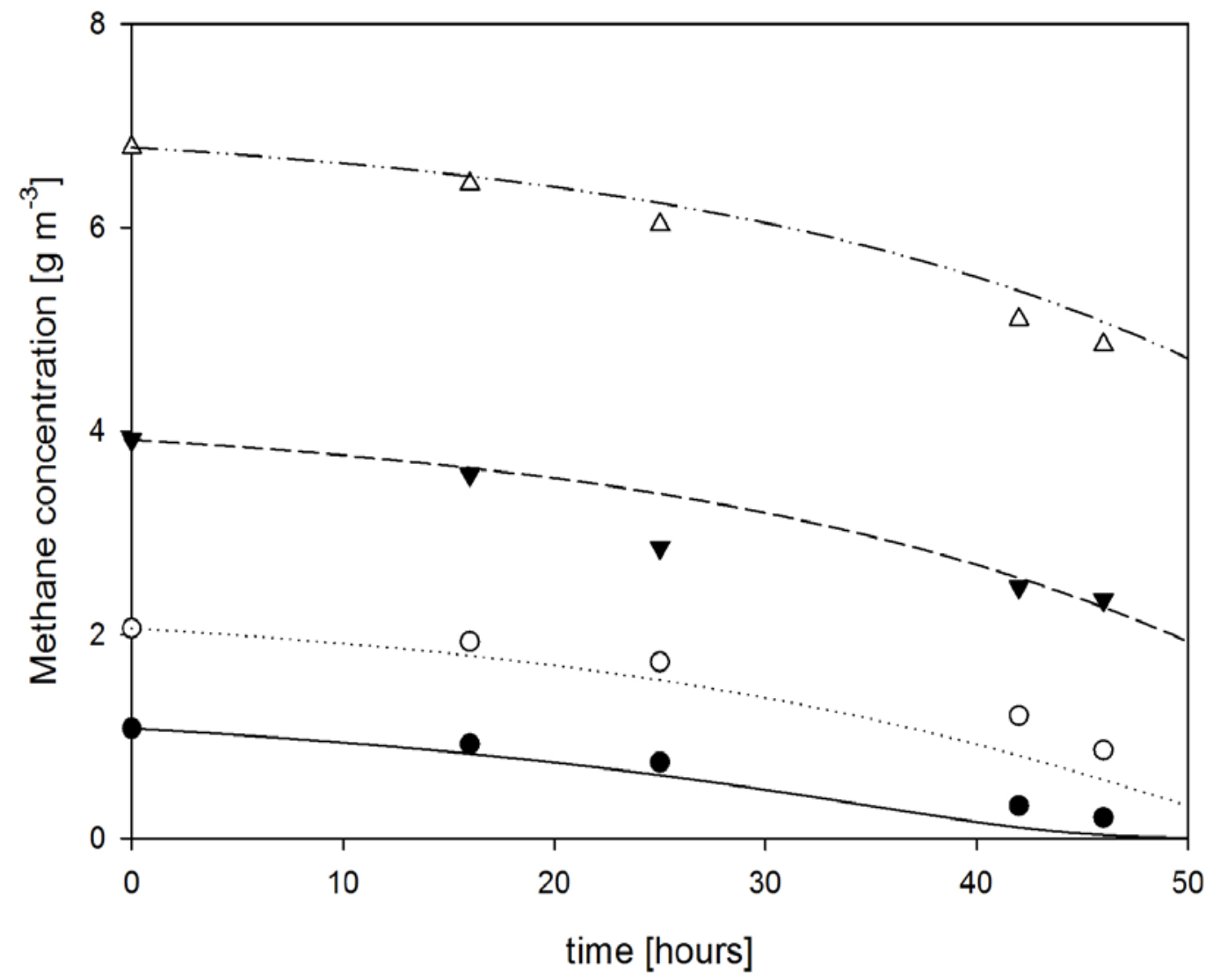


Figure 8 was created with MatLab.

a)

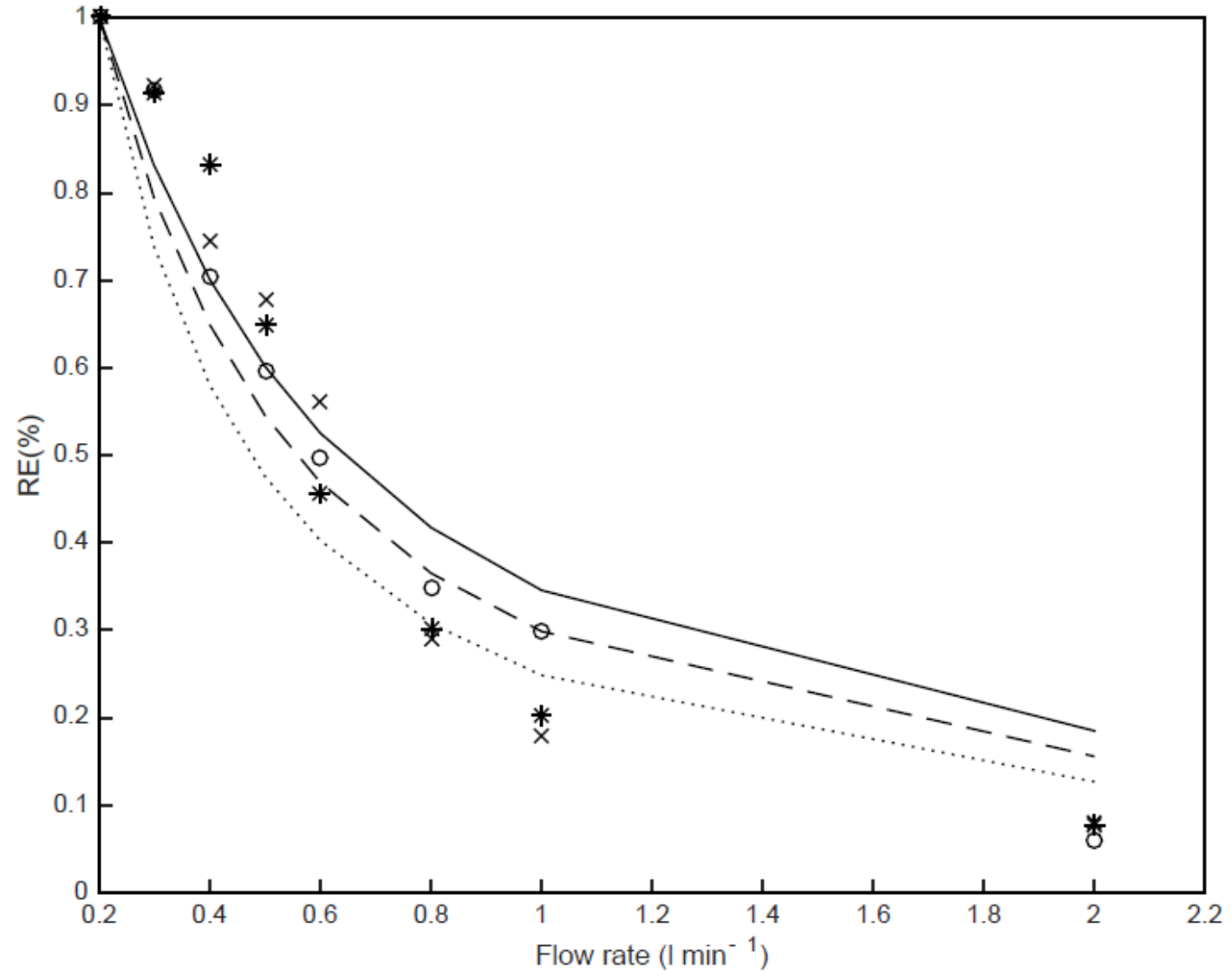


b)

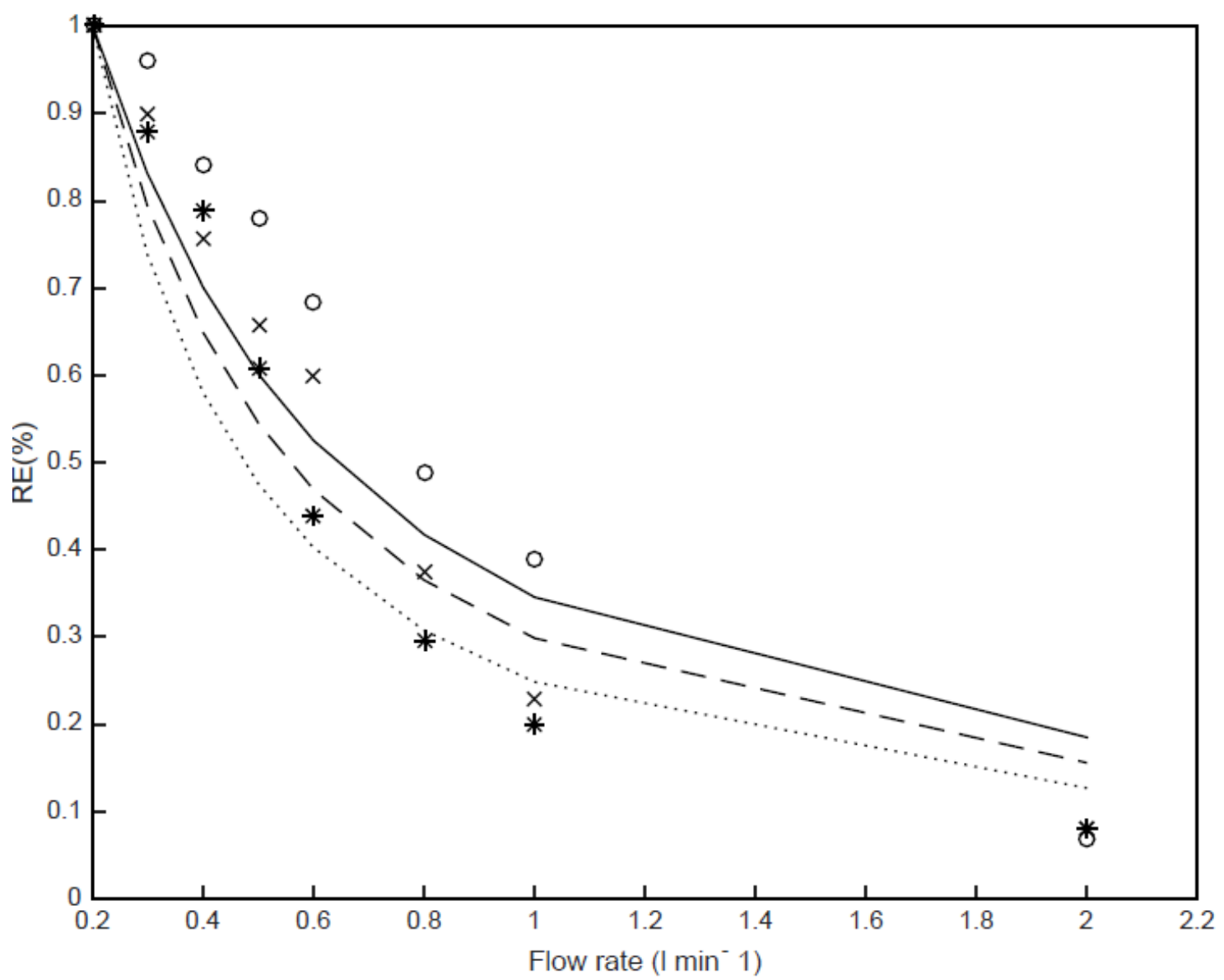


Table 1 Bio-oxidation of $\mathrm{CH}_{4}$ in different reactors with different inoculum and packing materials

\begin{tabular}{|c|c|c|c|c|c|c|c|c|}
\hline Reactor & Inoculum & Packing & $\begin{array}{l}\mathrm{L}_{\mathrm{CH} 4} \\
\left(\mathrm{~g} \cdot \mathrm{m}^{-}\right. \\
\left.{ }^{3} \cdot \mathbf{h}^{-1}\right)\end{array}$ & $\begin{array}{l}\mathbf{E C}_{\max } \\
\left(\mathbf{g} \cdot \mathbf{m}^{-}\right. \\
\left.{ }^{3} \cdot \mathbf{h}^{-1}\right)\end{array}$ & $\begin{array}{l}\text { Void } \\
\text { fraction }\end{array}$ & $\begin{array}{l}\text { Specific } \\
\text { area }\left(\mathrm{m}^{-}\right. \\
\left.{ }^{1}\right)\end{array}$ & $\begin{array}{l}E C_{s p} \\
\left(g \cdot \mathbf{m}^{-}\right. \\
\left.{ }^{2} \cdot \mathbf{h}^{-1}\right)\end{array}$ & Reference \\
\hline $\begin{array}{l}\text { Biotrickling } \\
\text { filter } \\
\text { (Multiphase) }\end{array}$ & $\begin{array}{l}\text { Methanotrophic } \\
\text { consortium isolated } \\
\text { from WWTP }\end{array}$ & $\begin{array}{l}\text { Polyurethane } \\
\text { foam With } \\
10 \%(\mathrm{v} / \mathrm{v}) \text { of } \\
\text { silicon oil as } \\
\text { nonaqueous } \\
\text { phase }\end{array}$ & $\begin{array}{l}157 \\
131\end{array}$ & $\begin{array}{l}22 \\
51\end{array}$ & $\begin{array}{l}0.97 \\
0.97\end{array}$ & $\begin{array}{l}600 \\
600\end{array}$ & $\begin{array}{l}0.037 \\
0.085\end{array}$ & $\begin{array}{l}\text { Rocha-Ríos et } \\
\text { al. } 2009\end{array}$ \\
\hline Biofilter & $\begin{array}{l}\text { Leachate from } \\
\text { methanotrophic } \\
\text { biofilter }\end{array}$ & $\begin{array}{l}\text { Expanded clay } \\
\text { Rock-5mm } \\
\text { Rock-2mm }\end{array}$ & 23 & $\begin{array}{l}5.0 \\
10.5 \\
17.3\end{array}$ & $\begin{array}{l}0.55 \\
0.40 \\
0.37\end{array}$ & $\begin{array}{l}470 \\
1250 \\
1360\end{array}$ & $\begin{array}{l}0.010 \\
0.008 \\
0.013\end{array}$ & $\begin{array}{l}\text { Nikiema et al. } \\
2010\end{array}$ \\
\hline Biofilter & Not specified & $\begin{array}{l}\text { Gravel ( } 4-8 \\
\mathrm{~mm} \text { ) }\end{array}$ & 25 & 14.5 & 0.40 & 8500 & 0.002 & $\begin{array}{l}\text { Girard et al. } \\
2011\end{array}$ \\
\hline Biofilter & $\begin{array}{l}\text { Indigenous } \\
\text { microorganisms } \\
\text { from the packing } \\
\text { material }\end{array}$ & Compost & 29 & 27.5 & $\begin{array}{l}\text { Not } \\
\text { specified }\end{array}$ & $\begin{array}{l}\text { Not } \\
\text { specified }\end{array}$ & $\begin{array}{l}\text { Not } \\
\text { specified }\end{array}$ & $\begin{array}{l}\text { Haubrichs and } \\
\text { Widmann } \\
2006\end{array}$ \\
\hline Biocover & Not specified & $\begin{array}{l}\text { Manure } \\
\text { compost/saw } \\
\text { dust }(9: 1)\end{array}$ & 9 & 5 & 0.41 & $\begin{array}{l}\text { Not } \\
\text { specified }\end{array}$ & $\begin{array}{l}\text { Not } \\
\text { specified }\end{array}$ & $\begin{array}{l}\text { Perdikea et al. } \\
2008\end{array}$ \\
\hline $\begin{array}{l}\text { Biotrickling } \\
\text { filter }\end{array}$ & $\begin{array}{l}\text { Lixiviate from } \\
\text { biofilter treating } \\
\mathrm{CH}_{4}\end{array}$ & $\begin{array}{l}\text { Clay spheres } \\
\text { Polypropylene } \\
\text { spheres Stones }\end{array}$ & 62 & $\begin{array}{l}10 \\
8 \\
21\end{array}$ & $\begin{array}{l}0.40 \\
0.90 \\
0.44\end{array}$ & $\begin{array}{l}310 \\
280 \\
470\end{array}$ & $\begin{array}{l}0.032 \\
0.029 \\
0.047\end{array}$ & $\begin{array}{l}\text { Avalos et al. } \\
2012\end{array}$ \\
\hline $\begin{array}{l}\text { Biotrickling } \\
\text { filter with } \\
\text { recirculation } \\
\text { of gas }\end{array}$ & $\begin{array}{l}\text { Methanotrophic } \\
\text { consortium isolated } \\
\text { from WWTP }\end{array}$ & $\begin{array}{l}\text { Polyurethane } \\
\text { foam in cubes } \\
\text { of } 1 \mathrm{~cm}^{3}\end{array}$ & 230 & 30 & $\begin{array}{l}\text { Not } \\
\text { specified }\end{array}$ & 1000 & 0.030 & $\begin{array}{l}\text { Estrada et al. } \\
2014\end{array}$ \\
\hline $\begin{array}{l}\text { Biotrickling } \\
\text { filter }\end{array}$ & $\begin{array}{l}\text { Methanotrophs type } \\
\text { I } \\
\text { (Methylomicrobium } \\
\text { album) and type II } \\
\text { (Methylocystis sp.) }\end{array}$ & $\begin{array}{l}\text { Polyethylene } \\
\text { rings ( } 1 \mathrm{~cm} \mathrm{id,} \\
1.2 \mathrm{~cm} \text { od, } 1 \\
\mathrm{~cm} \text { height) }\end{array}$ & 23 & 6.2 & 0.77 & 316 & 0.019 & This work \\
\hline
\end{tabular}


Table 2 Statistical analysis of experimental results in Biotrickling filters

\begin{tabular}{|c|c|c|c|c|}
\hline $\begin{array}{l}\text { Parameter } \\
\qquad \text { (Units) }\end{array}$ & $\begin{array}{l}\mathrm{EC} \\
\left(\mathrm{gCH}_{4} \mathrm{~m}^{-3} \mathrm{~h}^{-1}\right)\end{array}$ & $\begin{array}{l}\mathrm{pCO}_{2} \\
\left(\mathrm{gCO}_{2} \mathrm{~m}^{-3} \mathrm{~h}^{-1}\right)\end{array}$ & $\begin{array}{l}\mathrm{EC} \\
\left(\mathrm{gCH}_{4} \mathrm{~m}^{-3} \mathrm{~h}^{-1}\right)\end{array}$ & $\begin{array}{l}\mathrm{pCO}_{2} \\
\left(\mathrm{gCO}_{2} \mathrm{~m}^{-3} \mathrm{~h}^{-1}\right)\end{array}$ \\
\hline Degrees of freedom & 8 & & 4 & \\
\hline $\mathrm{T}_{\text {critical }}$ & 1.97 & 2.14 & 1.74 & 1.86 \\
\hline Student $t$ value & 7.03 & 7.51 & 2.05 & 2.07 \\
\hline
\end{tabular}

Table 3 Kinetic parameters for the bio-oxidation of $\mathrm{CH}_{4}$ by Methylomicrobium album and Methylocystis sp.

\begin{tabular}{lccccc}
\hline Parameter & Symbol & Methylomicrobium a. & Methylocystis sp. & (Units) & Reference \\
\hline Maximum specific growth rate & $\mu_{\max }$ & 1.16 & 1.10 & $\left(\mathrm{~d}^{-1}\right)$ & Fitted \\
Semi-saturation constant & $\mathrm{K}_{\mathrm{S}}$ & 0.29 & 0.43 & $\left(\mathrm{~g} \mathrm{~m}^{-3}\right)$ & Fitted \\
Biomass-substrate yield & $\mathrm{Y}_{\mathrm{X} / \mathrm{S}}$ & 0.28 & 0.28 & $\left(\mathrm{~g} \mathrm{~g}^{-1}\right)$ & Experimental \\
Partition coefficient & $\mathrm{H}$ & 29.4 & 29.4 & - & Literature \\
\hline
\end{tabular}

Table 4 Physical and kinetics parameters values for the bio-oxidation of $\mathrm{CH}_{4}$.

\begin{tabular}{|c|c|c|c|c|c|c|}
\hline Parameter & $\begin{array}{l}{\left[\mathrm{CH}_{4}\right]} \\
\left(\mathrm{g} \mathrm{m}^{-3}\right)\end{array}$ & $\begin{array}{l}\boldsymbol{\mu}_{\max } \\
\left(\mathbf{d}^{-1}\right)\end{array}$ & $\begin{array}{c}K_{\mathrm{S}} \\
\left(\mathrm{g} \mathrm{m}^{-3}\right)\end{array}$ & $\begin{array}{c}Y_{X / S} \\
\left(\mathrm{~g} \mathrm{~g}^{-1}\right)\end{array}$ & $\begin{array}{c}k_{g} \\
\left(\mathrm{~m} \mathrm{~h}^{-1}\right)\end{array}$ & $\begin{array}{c}D_{b} \\
\left(\mathrm{~m} \mathrm{~h}^{-1}\right)\end{array}$ \\
\hline Delhoménie et al. 2008 & $<10.4$ & 0.43 & 5.37 & $0.36-0.8$ & - & - \\
\hline Delhoménie et al. 2008 & $10.4-19.3$ & 1.09 & 7.59 & $0.36-0.8$ & - & - \\
\hline Menard et al. 2004 & $1.3-5.9$ & 0.79 & 6.13 & - & - & - \\
\hline Santos-Rodrigues et al. 2009 & 0.03 & 0.77 & - & 0.68 & - & - \\
\hline Boiesen et al. 1993 & - & $0.43-1.30$ & $0.05-0.19$ & $0.27-0.89$ & - & - \\
\hline Ordaz et al. 2014 & $1-20$ & 2.23 & 0.11 & 0.69 & - & - \\
\hline This work & $35-226$ & $1.10-1.16$ & $0.29-0.43$ & $0.14-0.40$ & 0.9 & $1.87 \cdot 10^{-5}$ \\
\hline
\end{tabular}

